\title{
Case Report: A 72 Years Old Man with Isaacs' Syndrome: A Rare Entity with Different Outcomes
}

\author{
Akam A. Saeed ${ }^{1,2 *}$, Zana A. Mohammed ${ }^{1,2,3}$, Rebeen R. Saeed ${ }^{1,2}$ \\ ${ }^{1}$ Shar Teaching Hospital of Sulaimania, Sulaimania, Iraq \\ ${ }^{2}$ General University Teaching Hospital of Sulaimania, Sulaimania, Iraq \\ ${ }^{3}$ School of Medicine, University of Sulaimania, Sulaimania, Iraq \\ Email: "akam.saeed@gmail.com
}

Received 3 February 2016; accepted 1 May 2016; published 4 May 2016

Copyright (C) 2016 by authors and Scientific Research Publishing Inc.

This work is licensed under the Creative Commons Attribution International License (CC BY). http://creativecommons.org/licenses/by/4.0/

(c) (i) Open Access

\begin{abstract}
Neuromyotonia is a neuromuscular hyperexitability disorder characterized by muscle stiffness caused by continuous muscle fiber activity. It is an immune mediated disorder with elevated antibody level against presynaptic, voltage gated potassium channels, either as isolation or as a paraneoplastic process. Symptoms usually include muscle twitching during rest (myokymia), cramps, peudomyotonia (delayed relaxation), increased sweating, and sometimes motor weakness. In this case report, we present a seventy-two years old man who presented with pain in both thighs for one month. It gradually became worse to involve feet and chest. His brain CT scan showed features of brain atrophy. EMG showed fasciculation along neuromyotonic discharges with characteristic wave in frequency and amplitude typical of Isaacs' syndrome. Potassium channel antibodies were very high. Diagnosis of Isaacs' syndrome was made. He was followed up for two months with treatment by three-day course of methyl prednisolone followed by oral steroid and methotrexate with much improvement. This is the first case of Isaacs' syndrome in Kurdistan.
\end{abstract}

\section{Keywords}

Issacs, Syndrome, Myokymia, Neuromyotonia, Neurology, Motor, Disorders, Hyperexcitability

\section{Introduction}

Isaacs' syndrome is a neuromuscular disorder characterized by muscle stiffness caused by continuous muscle

${ }^{*}$ Corresponding author.

How to cite this paper: Saeed, A.A., Mohammed, Z.A. and Saeed, R.R. (2016) Case Report: A 72 Years Old Man with Isaacs' Syndrome: A Rare Entity with Different Outcomes. World Journal of Neuroscience, 6, 82-84. 
fiber activity [1]. Voltage-gated potassium channels (VGKCs) are the targets [2]. Hyper excitability of the peripheral nerve can be induced by antibodies suppressing voltage-gated outward $\mathrm{K}(+)$ currents [3]. The first case of Isaacs' syndrome (also known as acquired neuromyotonia) was diagnosed in 1961 when two men presented with persistent, generalized muscle stiffness, in addition to electromyography which showed spontaneous, rapid discharges of motor-unit potentials [4].

\section{Case Report}

A 72 years old man presented with pain in both thighs for 1 month. It started gradually within few days. It later became severe disturbing sleep, relieved only modestly by pain killers. After 3 weeks, the pain involved both feet and chest. Furthermore, he developed fever and rigor, cough, and sputum with radiological features consistent with chest infection. He is Ex-smoker; quit before 5 years. He was a sheep seller. No family history of similar condition. Moreover, he is a known case of Hypertension and Atrial fibrillation for 3 years for which he is on candesartan and amiodarone, respectively.

Vitals were within normal. Consciousness, mental state, tone, power, reflexes, sensory, cerebellar signs and cranial nerve exam. were all normal. He had muscle fasciculation (myokimia) in both thighs (see video 1a) with severe tenderness. A full blood count revealed an erythrocyte sedimentation rate of 24 and Hematocrit $47 \%$ and negative CRP. Creatine kinase was normal. EEG was normal. Brain CT and MRI scan showed exaggerated periventricular white matter hypodensity, with normal CT scan of chest, abdomen and neck. LP was normal. Muscle biopsy was normal. Liver, renal, and thyroid function tests were also within reference limits. Potassium gated channel antibodies were very high. Nerve conduction studies were normal. EMG showed fasciculation along with neuromyotonic discharges with characteristic wave in frequency and amplitude typical of Isaacs' syndrome (look at video 2). Serum calcium, vitamin D, iron and ferritine, and phosphate levels were normal. ECG showed only left axis deviation. Moreover, antinuclear antibodies (ANA), anti double strand antibody, anti cytoplasmic antibodies (ANCA), CEA and CA 19-9, anti-SSA (Ro) Ab and anti-SSB (La) ab were all negative. Additionally, Hepatitis screen, HIV, VDRL, anti brucella and toxoplasma antibodies were negative. Protein electrophoresis showed a slight increase in gamma globulin. Bone marrow aspiration showed hypercellular state. OGD and colonoscopy were normal. The patient received methylprednisolone vial $500 \mathrm{mg}$ for 3 days, followed by oral steroid (prednisolone) $60 \mathrm{mg}$ daily for a month, then tapered weekly and meanwhile methotrexate started $7.5 \mathrm{mg}$ once a week with floic acid, vitamine D and carbamazepine. The patient became free of symptoms in two months (see vedio $1 b$ ).

\section{Discussion}

Radioimmunoassay of radioisotope labeled alpha-dendrotoxin-VGKCs solubilized from rabbit brain was the first method to identify antibodies to Voltage-Gated Potassium Channels (VGKC). Only a proportion of patients with acquired neuromyotonia (Isaacs' syndrome) were found to have detectable antibodies [5].

From the electrophysiological results it was seen that antibodies may decrease channel density rather than directly blocking the kinetics of VGKCs. The site of origin of spontaneous discharges, from electrophysiological, pharmacologic and immunologic studies, is located principally in the distal portion of the motor nerve [6].

Demonstration of antibodies against voltage-gated potassium channels suggests the autoimmune basis of this disorder, from any cause, paraneoplastic or acquired [1] [7]. The most commonly associated neoplasms are thymoma, small cell lung cancer, and Hodgkins lymphoma [8].

Muscle cramp, slow relaxation following muscle contraction, and excessive sweating (hyperhidrosis) are the main symptoms of Isaacs' syndrome [3] [6] [9]. Patients almost always develop persistent muscle contraction, which is often worse following exercise myokimia, generalized, and fasciculations are also common [10] [11].

Voltage-gated potassium-channel antibodies are detected in around $40 \%$ of patients with Isaacs' syndrome [10].

Electromyography shows features of spontaneous, continuous, irregularly occurring doublet, or multiplet single motor unit (or partial motor unit) discharges, firing at a high intraburst frequency as well as myokymic and neuromyotonic discharges. Fasciculations and fibrillation potentials are also frequent [12].

Myokymia, pseudomyotonia and contracture of hands and feet are the main features of Isaacs' syndrome. Clinical features and classic electromyographic findings establish the diagnosis of Isaacs' syndrome. Moreover, a proportion of cases have positive serum antibodies against Voltage-Gated Potassium Channels (VGKCs) [13]. 
The main lines of treatment are plasma exchange and intravenous immune globulin; other potentially effective treatments include phenytoin, carbamazepine, acetalozamide and diazepam [1] [14]. Remission usually occurs after 13 months ( 8 - 18 months) at which treatment can be stopped [12]. Treatment by immunoadsorption plasmapharesis is also reported [15].

\section{Conflict of Interest}

None.

\section{Competing Interest}

None.

\section{Contributorship}

Dr Akam A. Saeed and Dr. Zana A. Mohammed are the first authors, and the other is coauthor.

\section{References}

[1] Ahmed, A., Simmons, Z., et al. (2015) Isaacs Syndrome: A Review. Muscle Nerve, 52, 5-12. http://www.ncbi.nlm.nih.gov/m/pubmed/25736532/?i=17\&from=isaacs\%20syndrome

[2] Doi, H., Arimura, K., Ohyagi, Y. and Kira, J. (2011) Frostbite-Like Skin Lesion as an Autonomic Symptom of Isaacs' Syndrome. Journal of Internal Medicine, 50, 1113-1115. http://dx.doi.org/10.2169/internalmedicine.50.4998

[3] Arimura, K. and Watanabe, O. (2010) Immune-Mediated Neuromyotonia (Isaacs’ Syndrome) —Clinical Aspects and Pathomechanism. Brain Nerve, 62, 401-410.

[4] Gonzalez, G., Barros, G., Russi, M.E., Nuñez, A. and Scavone, C. (2008) Acquired Neuromyotonia in Childhood: Case Report and Review. Pediatric Neurology, 38, 61-63. http://dx.doi.org/10.1016/j.pediatrneurol.2007.07.009

[5] Watanabe, O. (2013) Neuroimmunological Diseases Associated with VGKC Complex Antibodies. Nihon Rinsho, 71, 915-920.

[6] Watanabe, O. (2013) Isaacs’s Syndrome and Associated Diseases. Rinsho Shinkeigaku, 53, 1067-1070. http://dx.doi.org/10.5692/clinicalneurol.53.1067

[7] Neosom-Davis, J., Buckley, C., Clover, L., et al. (2003) Autoimmune Disorders of Neuronal Potassium Channels. Annals of the New York Academy of Sciences, 998, 202-210. http://dx.doi.org/10.1196/annals.1254.022

[8] Walsh, J.C. (1976) Neuromyotonia: An Unsual Presentation of Intrathoracic Malignancy. Journal of Neurology, Neurosurgery \& Psychiatry, 39, 1086-1091. http://dx.doi.org/10.1136/jnnp.39.11.1086

[9] Kim, Y.M., Lee, S.H., Han, C.S., Choi, E.M., Choi, Y.R. and Chung, M.H. (2013) Anesthetic Experience Using Total Intravenous Anesthesia in a Patient with Isaacs' Syndrome-A Case Report. Korean Journal of Anesthesiology, 64, 164-167. http://dx.doi.org/10.4097/kjae.2013.64.2.164

[10] Maddison, P. (2006) Neuromyotonia. Clinical Neurophysiology, 117, 2118-2127. http://dx.doi.org/10.1016/j.clinph.2006.03.008

[11] Béquet, D., Devière, F., Renard, J.L. and Felten, D. (1997) Isaacs Syndrome: Long-Term Improvement with Intravenous Polyvalent Immunoglobulins. Revue Neurologique (Paris), 153, 602-604.

[12] Newsom-Davis, J. and Mills, K.R. (1993) Immunological Associations of Acquired Neuromyotonia (Isaacs’ Syndrome). Report of Five Cases and Literature Review. Brain, 116, 453-469. http://dx.doi.org/10.1093/brain/116.2.453

[13] Sukajintanakarn, D., Mitrabhakdi, E. and Phanthumchinda, K. (2006) Acquired Neuromyotonia (Isaacs’ Syndrome): A Case Report with Autonomic Physiologic Studies. Journal of the Medical Association of Thailand, 89, 1308-1312.

[14] Issa, S.S., Herskovitz, S. and Lipton, R.B. (2011) Acquired Neuromyotonia as a Paraneoplastic Manifestation of Ovarian Cancer. Neurology, 76, 100-101. http://dx.doi.org/10.1212/WNL.0b013e318203e91a

[15] Nakatsuji, Y., Kaido, M., Sugai, F., Nakamori, M., Abe, K., Watanabe, O., Arimura, K. and Sakoda, S. (2000) Isaacs' Syndrome Successfully Treated by Immunoadsorption Plasmapheresis. Acta Neurologica Scandinavica, 102, 271-273. http://dx.doi.org/10.1034/j.1600-0404.2000.102004271.x 